\title{
The transferability of western principles and values in the governance of sport
}

\author{
lan Henry
}

\section{Introduction}

The literature on the governance of sport has grown exponentially over the last two decades (Downing, Leopkey \& Smith 2018). This has been fuelled by heuristic concerns to describe and explain the evolving political economy of the sporting landscape, and by normative concerns to promote ethically sound, and managerially effective, practices in governing sport. However, the scoping review by Downing et al. implicitly highlights the western dominated nature of the English language literature on sport governance, identifying and reviewing some 243 articles published in academic journals on the topic between 1980 and 2016. A small but significant minority of these relate directly to non-western governance contexts or practices. The aim of this chapter is therefore to examine the significance of cultural differences in the identification and application of principles of sport governance.

The treatment of sport governance issues in non-western settings has for the most part focused on the shortcomings of approaches to sport governance in such contexts (e.g. McLeod, Shilbury \& Zeimers 2020). The implicit suggestion in many such sources is the argument that non-western practices need to undergo modernisation, by which is implied the adoption of the professionalisation and 'modern' governance practices of 'leading' nations in sport. This is a reflection of the modernisation agenda (implicit here in the sport literature, but often evident more broadly in social commentary) in which there is an underlying assumption that the 'progress' achieved and enjoyed within sport governance in the West represents the model to be emulated by the non-west. The nature of western governance practices is not without its critics, indeed much has been written about the shortcomings of such practices in the literature, but there does seem to be an assumption that good practice is defined by the 'developed' sporting nations of the West.

Theories concerning the modernisation of sport, and the inevitable convergence (or the desirability of convergence) of governance systems may be subject to the same fundamental critique as modernisation theories more generally. Fourie (2012), for example, characterises traditional theories of modernisation as 
suffering from flawed fundamental teleological assumptions. These include that modernisation is a single, unified, homogenising process, with the West providing the key points of reference in the 'onward march of progress'. The teleological assumption here is one which predetermines what will count as progress, that is the development of the institutions associated with modernity and modernisation. In generic terms this includes institutions such as liberal democracy, capitalism and the bureaucratic state (Fourie 2012, p. 54) such that those societies not exhibiting these features might be regarded as not having reached a mature stage of modernity. In terms of modernisation specific to sport, equivalent phenomena might include the autonomy of sport, commercialisation and sponsorship, and transnational regulation in the form of sport-specific bodies such as WADA, and generic regulators such as the European Union which represent the institutional signposts of modernity to be embraced along the way in the journey towards modernity in sport and its governance.

The rejection of such teleological assumptions has been promoted by those who have drawn the conclusion that modernity is not a homogeneous phenomenon since it will take on different forms (culturally, politically, and/or economically) in different contexts, and who therefore advocate the notion of 'multiple modernities' (Eisenstadt 2017) in which different instances of the phenomenon of modernity share a 'family resemblance' (Wittgenstein 1972) of overlapping characteristics rather than a unitary set of features attributable to a single model. What this chapter therefore seeks to do is to investigate the distance between western and non-western governance prescriptions, and practices and their implications for the governance of sport.

\section{Meanings of governance}

The uses of the term governance are multiple with different denotations (referring to different concepts or phenomena) and different connotations (drawing on different theoretical traditions and perspectives). Bevir (2009) provides a brief but well-illustrated map of the governance field, highlighting the range of such denotations and their connotative relationships to theory. In particular he locates the emergence of a concern with governance, as opposed to government, with the New Public Management of the 1990s in which direct provision of services by government gave way to forms of enabling of the voluntary and/or private sectors to deliver services and desired policy outcomes.

In an early attempt to characterise the dominant themes in governance policy and research, a distinction was made between what was argued to be the three most common and significant uses or conceptualisations of the term sport governance in the literature (Henry \& Lee 2004). ${ }^{1}$ The first of these is systemic governance, which rejects the characterisation of power in business or policy environments as hierarchical, or top-down. Instead, most such environments, including those of sport business or sport policy are characterised by the interaction of organisations and of groups working in horizontal networks within and 
across organisations. Such groups might include media interests, major sponsors, players' agents, the major sport clubs and their shareholders in professional sport, as well as 'governing bodies' such as the IOC or FIFA, with power exercised not within a fixed, vertical, hierarchy, but where identifying the sets of actors which will be dominant will depend on the nature of the issue being dealt with, and the resources available to such actors in specific contexts. Systemic governance is thus concerned with the competition, cooperation and mutual adjustment between organisations in such transversal systems.

The second major application of the notion of governance is that of corporate, or 'good organisational governance' which refers to the accepted norms or values for the just means of allocation of resources, and profits or losses (financial or other) and of the conduct of processes involved in the management and direction of organisations in the sport business (Henry \& Lee 2004).

The third major application of the term governance in sporting contexts is that of 'political governance'. This relates to the processes by which governments or governing bodies are characterised as seeking to steer the sport system to achieve desired outcomes by, for example, moral pressure, use of financial or other incentives, or by forms of licensing, or regulation to foster action by parties other than government (or sporting authorities such as governing bodies) to act in ways consistent with desired policy outcomes. This analogy of steering rather than rowing (Osborne \& Gaebler 1992) is associated with the neoliberal distrust of state action and subsequent reliance on commercial or third sector agency.

While most of the discussion which follows in this chapter relates in particular to the nature of occidental and oriental values in good organisational, or corporate governance, and problems associated with the transferability of such values and prescriptions to non-western contexts, it is worth highlighting some preliminary points about cultural specificity and issues associated with systemic governance and political governance, and non-western engagement with the western dominated sport system.

Prior to the end of the Cold War systemic governance of sport had traditionally been dominated by a set of core western nations, with a semi-periphery of Eastern bloc countries pressing for representation and influence on the global sporting stage, and a periphery of countries largely in Africa and Asia, who were, for the most part, passive recipients of, rather than participants in, global sporting decision-making (Al-Tauqi \& Henry 2008). Within the Olympic movement, for example, the overrepresentation of Western Europe, and the United States in the IOC and related decision-making bodies, in sponsorship roles, in sport media, in hosting major events, and in financial investment in sport, has been challenged in ways which have had a profound impact on sport governance (Amara 2008, 2012). Recently, this has been most evident in the attraction of rights to host major sporting events in the Gulf states, locations such as Dubai, Abu Dhabi, Bahrain, and perhaps most notably by Qatar's successful bid to host the 2022 FIFA World Cup. This last example is a high profile (and some might argue a high risk) attempt to promote national image through a soft power 
strategy (Brannagan \& Giulianotti 2018; Dorsey 2015). Even Saudi Arabia, the largest of the Gulf economies with the biggest population, which had, until recently, been a relative bystander in terms of sport policy and sport hosting, has adopted an explicit use of sport for political purposes. Commentators ascribe the country's recent engagement with sport to 'sportswashing': "Saudi Arabia's relatively sudden interest in sport can be construed as a soft power tactic to help distract from the kingdom's ongoing human rights abuses and the Yemen crisis. ... More recently, Saudi Arabia's sport-centric lobbying offensive has been the result of an urgent need for the kingdom to rebrand itself following the murder of Jamal Khashoggi, a US-based Washington Post columnist and Saudi dissident" (Zidan 2019).

The arrival of non-western capital investment in European soccer has had a profound effect, not simply on those clubs subject to investment-Manchester City and Paris St German being perhaps the highest profile cases-but also on players' salaries and transfer fees, and on the development of networks of investment. Sheikh Mansour bin Zayed Al Nahyan's purchase of Manchester City was the initiation of an ambitious project that has transformed world football. City Football Group invested not simply in Manchester City, but launched New York City FC, and invested in clubs in Australia, Japan and Spain (Sleightholm 2018). Its impact on the nature of inter-club competition (in which oligopolistic trends have been reinforced), and on relations between club owners and local fans, would have been unimaginable only a decade or so ago, and thus such non-western actors can now hardly be described as occupying the periphery of systemic sporting relations. The systemic governance of professional sport in the 2020s is thus of a different order to that which obtained in the 1990s.

In relation to political governance, an issue which is more prominent in non-western contexts is that of claims of government interference in the activities of sporting bodies which challenge sporting autonomy. In particular the IOC regularly addresses problems involving government influence on the make-up of National Olympic Committees (NOC). Rule 28(9) of the Olympic Charter seeks to protect the autonomy of sport, providing for suspension of a NOC where any governmental body has hampered the actions of the NOC. Recent examples of disputes between the IOC and governments include the suspension of the Indian Olympic Association in 2012 for breaching the requirements of the Olympic Charter; Iraq in 2008 for government intervention in the workings of its NOC; and Kuwait in 2015 over a new sports law which the IOC claimed impacted upon the autonomy of the Olympic movement. Such invoking of sanctions in the case of state intervention in the workings of a NOC is virtually exclusive to cases of nations of the global south. Interestingly, however, no action has been taken by the IOC in respect of governments such as Russia, China, and other former communist-led states known to exert direct influence on the membership of their NOCs. ${ }^{2}$ These cases of government 'interference' in the autonomy of action of sporting bodies imply a rejection of a political governance approach of 'steering' in favour of direct control of decision-making. 


\section{Good corporate governance: Core values and the response of the non-west}

While the concepts of systemic and political governance of sport might be said to be primarily heuristic, explaining the patterns of influence developing in sport, 'good' or 'corporate' governance provides a clearly prescriptive approach advocating the principles or values to be adopted or reflected in governance practices in sport. The list of principles of good governance varies to some degree from one source to another. For example, while the European Commission (2019) cites the basic principles of good governance in sport as 'integrity', 'accountability', 'transparency', 'democracy', 'participation' and 'inclusivity' the European Parliament (2017) cites the seven principles, identified in Henry and Lee (2004), namely transparency, accountability, democracy, responsibility, equity, effectiveness, and efficiency, which overlap to a significant degree in terminology and substance with the Commission's, and Geeraert's (2015) report of the Sports Governance Observer reduces the basic principles to four key dimensions-transparency and public communication, democratic process, checks and balances, and solidarity. A useful overview of the range of principles cited by 21 different bodies and nine academic authors is provided in Chappelet \& Mrkonjic (2013).

Perhaps the core question in terms of the transferability or imposition of western principles and/or values relates to the extent to which there is a convergence of governance principles and practice both de jure (in the adoption of principles as stipulated requirements) and/or de facto (in the actual practices of organisations and individuals in sporting governance). The most widely cited account of pressures placed on institutions, organisations and individuals to conform to established organisational practices is the seminal account of DiMaggio and Powell (1983), who define three modes of isomorphic pressure namely, coercive, mimetic, and normative, which operate in a manner which reinforces the position of dominant actors within a particular field (in our case the field of sport governance). Coercive measures would include the use of legislative measures, or international regulatory frameworks. Mimetic isomorphism is a product of actors following the form, style, and modus operandi of other, 'leading' organisations operating in the field of sport. Normative pressures relate to the impact of formal and informal codes of practice advocating values and systems of governance, such as the IOC's Basic Universal Principles of Good Governance of the Olympic and Sports Movement (IOC 2008).

In contrast to isomorphic factors promoting convergence in governance practices, there are also local political, economic and educational factors which reinforce localism or cultural specificity of practices. As discussed above the political history of a nation state can be reflected in the expectations concerning the relationship between the state and civil society. Path dependency (Johnson 2001; Mussagulova 2020) is clearly reflected in post-Soviet history of sport governance not simply in issues such as state 'interference' in the appointment of members of NOC related bodies, but also in terms of state control of a 
corrupt anti-doping system which persisted at least up until the Sochi Olympics when WADA identified the state's role in this practice (McLaren 2016). The economic context of sport governance is also a potentially constraining factor, with some small organisations, such as small NOCs with limited resources, unable to perform those governance tasks which are expensive and resource intensive, with, for example, some countries being unable to meet the costs of drug testing for even a small number of athletes. The impact of education (in particular management education), or lack of exposure to it, is noted by McLeod et al. (2020) as a factor which can promote convergence or cultural specificity. In reviewing sport governance convergence in India, the authors identify a perception that "domestic sport management programs are underdeveloped in the country, and thus, India is lacking a key mechanism through which the importance of good governance principles is typically taught in other parts of the world" (McLeod et al. 2020). However, as noted earlier in the findings, many Indians travel abroad to study sport management and thus good governance principles, and their impact on sport organisations are transfused to India through normative isomorphic pressures emanating from international educational networks. Nevertheless, despite this, the lack of established management education and training programs in the domestic context constitutes a significant barrier to convergence.

However, while political and economic factors may be significant influences in maintaining the divergence of practices in sport governance, cultural factors may provide a more subtle impact. Here we will focus on two examples, namely, the practice of guanxi in Chinese society, and more broadly of political clientelism. Guanxi is a practice which draws on Confucian thought, locating individuals in a set of reciprocal and trust-based, familial and social, and potentially political and business, hierarchical relations of obligation, such that guanxi relations can play an important role in deciding who will do business with whom. Western perspectives on guanxi often link this to corrupt business or political practice (Fan 2002). However, the practice of guanxi is not necessarily associated with dishonest or unethical practices. It may simply imply taking into account the level of trust or confidence one party has in another party's ability to deliver what has been promised (Barbalet 2018). Taking account of such considerations might be regarded as common sense, and indeed as an obligation in making sensible business judgements.

However, while there is no necessary connection between guanxi and unethical or corrupt practices, examples of unethical practice in government, in the judicial system (Li 2018), in business activity (Chang 2018), and even in the buying and selling of positions in the military in China (Wang 2016), are widely acknowledged. The existence of this phenomenon, and the need to take account of it when conducting business, may well undermine the ability of managers de facto to respect good governance principles including those promoted by European bodies such as the European Commission, or by the IOC in its declaration of the basic universal principles of good governance. 
There are two important points to make in response to cultural factors undermining the promotion of good governance. The first is that this is not restricted to Chinese social and business practices There are equivalent 'culturally specific' phenomena in other societies- see for example the concepts of 'blat' in Russia or 'vruzki' in Bulgaria (Hsu 2005; Onoshchenko \& Williams 2014; Williams \& Yang 2017) as well as in western societies. In the UK, the existence of 'old boys networks' is evidenced in, for example, the analysis by Reeves et al. (2017) of membership of Britain's political, law, business, cultural and military elites, which highlights that those educated at Britain's nine top private, fee-paying 'public' schools, "are about 94 times more likely to reach the British elite than are individuals who attended any other school" (Reeves et al. 2017, p. 1141).

The second point to make is that any assumption that western de jure governance arrangements will inevitably be superior to non-western approaches can be seen, in Said's (1991) terms, as a dangerously orientalist conjecture. We can highlight here the failure of major US professional leagues including the National Football League and Major League Baseball to adopt the WADA code with the consequence that an athlete recording a doping violation can receive a two week ban for an offence that would incur a minimum of a four-year ban under WADA rules (Morgan 2020).

If we turn to other cases of negative de facto behaviours in sporting governance, political clientelism (and other related forms of vote buying) are said to be a feature of traditional, non-western, rather than modern societies, and thus likely to be less evident in the developed economies of the West. Political clientelism relates to the exchange of material benefits (good, services, jobs, etc.) provided to a client from a political patron in exchange for political support (Allen 2011). A study of strategic relations and patterns of sport funding in Greece in the 1980s and early 1990s, for example, highlights how changes in elected national government from the Greek socialist party PASOK, to the economically liberal New Democracy were systematically associated with increased or decreased funding of those national sport federations whose president was a member of the incoming or outgoing party of government (Henry \& Nassis 1999; Nassis 1994). Similar patterns of party-based favouritism have been identified in Turkish sport policy (Erturan-Ogut \& Sahin 2014).

Political clientelism has historically been associated with pre-modern political contexts, hence its association with Southern European non-industrial economies. As a form of political behaviour, clientelism has been expected to decline as the development of modernity is associated with allocation of resources in society based on modern, 'rational', 'technocratic' criteria rather than on social obligations. However, its persistence in modern politics, for example in the context of contemporary populist, ethno-nationalist politics of Trump's presidential election campaigns, (Bonikowski 2019), is evident where benefits are selectively targeted at the constituencies of supporting those in power.

There are numerous examples of the inappropriate use of clientelistic incentives for political gain in modern industrialised economies. High profile 
examples of clientelism in a modern western state include the resignations of two of Australia's ministers with responsibility for sport, namely Ros Kelly from the Keating government in 1994 (Wright 2020), and Bridget McKenzie from the Scott Morrison government in 2020 (Murphy 2020), following accusations of the targeting of marginal electoral constituencies in terms of allocation of community sport grants in order to influence the electorate, or 'buy votes'. Such cases demonstrate the unexceptional survival of political selfinterest in funding decision-making, in place of the use of modern, technocratic, and logically argued principles for financial allocations (Di Francesco 2020; Smith 1999).

Thus, to summarise there is a variety of de facto and de jure differences in relation to governance practices generally, and in relation to sport specifically, between, but also importantly within western and non-western societies.

\section{Seeking universal principles of good governance across cultures}

Is universal agreement around social and political values feasible at all? One of the most influential arguments at a macro level of analysis which was evident in neo-conservative approaches to policy in the post-Cold War environment and which promoted the notion that convergence of values was impossible, was Samuel Huntington's 'clash of civilisations thesis'. Huntington argued that with the end of the Cold War era, the bi-polar politics of the East-West divide was replaced by a world constituted by nine civilisational blocks, Western, Latin American, African, Islamic, Sinic, Hindu, Christian Orthodox, Buddhist and Japanese, with multipolar values. Some commentators subsequently promoted the view that these blocks sponsor competing and incompatible foundational value stances which, at base, are not open to negotiation and hence compromise. This position may not be that which Huntington himself intended to convey and might be more closely associated with Francis Fukuyama's characterisation of the end of ideological debate in his book The End of History and the Last Man (Fukuyama 1993). As Kim and Hodges argue: "Civilisational coexistence is possible in Huntington's paradigm, whereas such coexistence seems to be impossible in Fukuyama's because the latter's paradigm of monocentric diffusion recognises no standard of civilisation other than the Western one" (Kim \& Hodges 2005, p. 217).

There are two fundamental points to take issue with here. The first is that the argument that these cultures represent separate, pillarised, value systems is unconvincing (Tibi 2001). There is often far more commonality of values across these civilisational blocks, than there is within them. So, for example, Muslim, Christian, Jewish and secular feminist groups would often have more in common across cultures with one another than they would with the conservative patriarchal values of the male establishment within their own cultures. The notion of 'hermeneutically sealed' civilisational blocks associated with different value 
systems, and thus with differences in prescriptions of good governance is thus an erroneous oversimplification (Henry 2007).

The second point is that not only are such claims about the separation of civilisational blocks erroneous they are also dangerous. As Kim and Hodges argue: "Fukuyama's civilisational Paradigm of monocentric diffusion (...) seemingly [became] an epistemic basis for the neoconservative foreign policy of the Bush administration" (Kim \& Hodges 2005, p. 217).

So, from the neo-liberal, neo-conservative wing, support for an account of the convergence of political values around neo-liberalism has been generated. However, the explanatory force of (and support for) Fukuyama's argument has declined, with events such as 9/11, the financial crisis of 2007-8, the Arab Spring, and the failure of militarily enforced 'democratisation' of Iraq and Afghanistan (Milne 2012). The claimed inevitability of accepting neo-liberal values has thus been undermined.

While, from the perspective of the political right, the convergence of values around neo-liberalism was described in a teleological narrative, from a leftist perspective, a negotiated convergence of values through discourse is promoted in the discourse ethics approach developed by Jurgen Habermas (1984, 1990, 1992). Indeed, Habermas's account of how discourse can be employed to foster consensus offers a philosophically sophisticated, but practical and inclusive, approach to achieving value consensus that can have clear implications for organisational management. Meisenbach (2006) provides an account of a practical case of a discourse ethics approach, which has been adapted below for the purposes of illustrating its application to decision-making criteria in the context of selection and application of criteria of good governance for a governing body of sport (see Table 15.1).

In this account the selection and application of criteria of good governance, and the identification of relevant stakeholders, is undertaken on the basis of Habermas's requirements for the exercising of discourse. Habermas defines discourse as any social interaction involving opposing or alternative viewpoints aimed at achieving a new rational consensus (Habermas 1995). His discourse ethics does not seek to define or prescribe what is ethical (normative ethics), but outlines a procedure, which is based in intersubjective communication for addressing questions of what is ethical (meta-ethics). That procedure is a form of testing norms through practical communication in an inclusive and non-coercive rational discourse.

Development of the means of an inter-cultural agreement of what should constitute principles of good governance can thus, it is claimed, be drawn from Habermas's discourse ethics approach. The practicalities of generating this means of agreement are briefly outlined in Table 15.1, where Meisenbach's description of the steps to be taken in applying a discourse ethics approach to a specific business case study, is extended in the middle column of the table to the practical task of identifying and defining principles of good governance in a particular (but undefined) sporting context. Of course, there are problems in the adoption of 
Table 15.I Steps in the development of a discourse ethics framework

\begin{tabular}{|c|c|c|c|}
\hline Steps & Description & $\begin{array}{l}\text { Application to National/ } \\
\text { International Sporting Contexts }\end{array}$ & $\begin{array}{l}\text { Issues to address at } \\
\text { each stage }\end{array}$ \\
\hline Step I & $\begin{array}{l}\text { Generate an } \\
\text { utterance or } \\
\text { potential norm }\end{array}$ & $\begin{array}{l}\text { Specify criteria of good } \\
\text { governance in sport, e.g. } \\
\text { gender equity in leadership } \\
\text { roles in sport organisations. }\end{array}$ & $\begin{array}{l}\text { Defining terms, meaning; } \\
\text { use of strategic } \\
\text { ambiguity. }\end{array}$ \\
\hline Step 2 & $\begin{array}{l}\text { Determine who is } \\
\text { potentially affected } \\
\text { by the enactment } \\
\text { of the utterance }\end{array}$ & $\begin{array}{l}\text { Identify stakeholders: } \\
\text { nationally and internationally, } \\
\text { players, coaches, } \\
\text { administrators, etc. }\end{array}$ & $\begin{array}{l}\text { Guarding against } \\
\text { organiser/convenor } \\
\text { control and bias in } \\
\text { selecting stakeholders; } \\
\text { determining expanding } \\
\text { circles of those } \\
\text { affected. }\end{array}$ \\
\hline Step 3 & $\begin{array}{l}\text { Articulate the } \\
\text { utterance to all } \\
\text { parties identified } \\
\text { in Step } 2\end{array}$ & $\begin{array}{l}\text { Articulate the criteria of good } \\
\text { governance proposed to all } \\
\text { stakeholders identified: e.g. } \\
\text { gender equality or equity; } \\
\text { targets or quotas. }\end{array}$ & $\begin{array}{l}\text { Dialogic articulation of } \\
\text { utterance; practicality } \\
\text { in defining conformity } \\
\text { to norm(s). }\end{array}$ \\
\hline Step 4 & $\begin{array}{l}\text { All parties } \\
\text { discursively debate } \\
\text { the consequences } \\
\text { and their } \\
\text { acceptability }\end{array}$ & $\begin{array}{l}\text { All stakeholders engage in full } \\
\text { and open discussion. }\end{array}$ & $\begin{array}{l}\text { Equal and full } \\
\text { participation; } \\
\text { practicality. }\end{array}$ \\
\hline Step 5 & $\begin{array}{l}\text { Make a judgment } \\
\text { about the validity } \\
\text { and acceptability } \\
\text { of the proposed } \\
\text { utterance or norm }\end{array}$ & $\begin{array}{l}\text { Decision taken in respect of } \\
\text { application of ethical norms: } \\
\text { e.g. anticipated norms; means } \\
\text { adopted to achieve } \\
\text { outcomes; sanctions. }\end{array}$ & $\begin{array}{l}\text { Handling disagreement; } \\
\text { privileging consensus. }\end{array}$ \\
\hline
\end{tabular}

Source: Adapted from Meisenbach (2006, p. 46).

this simplified model of decision-making. For example, in the real world, especially perhaps in inter-cultural discussions, not all participants in the discourse, or stakeholders, come to the table with equal resources such that all voices can be heard (with the result that principles of governance are for some groups imposed rather than discursively agreed). Furthermore, I have argued elsewhere (Henry 2007) that, while in practical terms universal agreement may be unattainable, nevertheless the approach has value in that general consensus among a majority might be reached by such a strategy. ${ }^{3}$

As an example of the practical outcomes that might be obtained. Ghadami and Henry (2015) outline in a case study of national governing bodies of sport in Iran, the development of a system for establishing local cultural preferences for specific criteria of good governance, and for weighting those criteria in a manner reflecting local priorities, employing the Analytic Hierarchy Process technique developed by Saaty (1980) to evaluate and weight alternatives in decisionmaking. The approach adopted promotes discourse about which governance 
criteria are important to the local Iranian sporting community; how performance by particular sporting bodies might be measured (which operational indicators to employ); identifying the level of achievement of particular sporting bodies against those indicators; and allowing comparison and ranking of the performance of a range of sporting bodies which might be used, for example, for the purposes of deciding differentials in levels of financial grant allocations.

\section{Concluding remarks}

In the introduction to this chapter we highlighted the connection between arguments concerning the modernisation of sport and the modernisation thesis more generally. This was in part to warn against simplistic teleological accounts promoting a picture of an inevitable march towards cultural uniformity around western models of sport. Of course, with the advent of supranational bodies, or codes such as the WADA code, national bodies are required to sign up to the rules (de jure) though their local (de facto) conformity with the rules may be variable, but with supranational bodies seeking (for example through the Court of Arbitration in Sport) to enforce compliance.

However, in discussing this matter we should perhaps seek to avoid falling into the habit of the use of binary distinctions, the traditional and the modern; Islam and the West; religious and secular world views. Even the governance of sporting activities which have developed in particular contexts, such as professional football (soccer) manifests considerable variation as a phenomenon (Amara 2003; Amara \& Henry 2004; Henry, Amara, Liang \& Uchiumi 2005), in which local features persist and develop in parallel with the impact of globalising (or at least non-local) influences, evident in aspects of governance which have undergone modernisation. These enduring local diversities alongside the pressure for the uniform application of global rules means that the modernisation of sport is liable to take on subtly different forms in different local contexts which are modern but not uniform, supporting in effect a form of 'multiple modernities' (Wittrock 2002). The departure from globalising norms is not simply a feature of 'modernising' systems (such as gender inequities in the non-west), it is also a feature of 'advanced' sporting nations, as for example in the US adoption of double standards in anti-doping policy for American football and baseball as compared with Olympic sport. There is thus greater promise to be held out in promoting agreement concerning the processes through which sport governance principles should be decided, rather than in the imposition of definitive principles per se.

\section{Notes}

1. Despite the simplicity of the typology, it continues to have an heuristic value as evidenced by its subsequent use by a number of authors in reviewing the field since its initial introduction (e.g. Bruyninckx 2012; Downing et al. 2018; Winand \& Anagnostopoulos 2019). 
2. The explanation for this given by a senior IOC official in conversation with the author in May 2007, was that no formal complaints of illegitimate government intervention had been received by the IOC in relation to the work of these NOCs.

3. This promotion of a neo-Habermasian account is of course one with which purist 'Universal Pragmatists' would certainly take issue.

\section{References}

Al-Tauqi, M \& Henry, I 2008, 'The Historical Development of Olympic Solidarity: Evaluating Alternative Perspectives', International Journal of History of Sport, vol. 25, no. 3, pp. 355-69.

Allen, H 2011, 'Clientelism', Annual Review of Political Science, vol. 14, no. 1, pp. 289-310. doi:10.1146/annurev.polisci.031908.220508

Amara, M 2003, Global Sport and Local Modernity: The Case of Professionalisation' of Football in Algeria, Dissertation, Loughborough University, Loughborough.

Amara, M. 2008, 'The Muslim World in the Global Sporting Arena', The Brown Journal of World Affairs, vol. 14, no. 2, pp. 67-76.

Amara, M 2012, Sport, Politics and Society in the Arab World, Palgrave, Basingstoke. doi: $10.1057 / 9780230359505$

Amara, M \& Henry, I 2004, 'Between Globalisation and Local Modernity: The Diffusion and Modernisation of Football in Algeria', Soccer and Society, vol. 5, no. 1, pp. 1-26.

Barbalet, J 2018, 'Guanxi as Social Exchange: Emotions, Power and Corruption', Sociology - The Journal of the British Sociological Association, vol. 52, no. 5, pp. 934-49. doi: $10.1177 / 0038038517692511$

Bevir, M 2009, Key Concepts in Governance, Sage, London. doi:10.1515/9781400836857

Bonikowski, B 2019, 'Trump's Populism: The Mobilisation of Nationalist Cleavages and the Future of U.S. Democracy', in K Weyland \& R Madrid (eds), When Democracy Trumps Populism: Lessons from Europe $\mathcal{E}$ Latin America, Cambridge University Press, New York, pp. 110-31. doi:10.1017/9781108692793.006

Brannagan, PM \& Giulianotti, R 2018, 'The Soft Power-Soft Disempowerment Nexus: The Case of Qatar', International Affairs, vol. 94, no. 5, pp. 1139-57. doi:10.1093/ia/iiy125

Bruyninckx, H 2012, 'Sport Governance: Between the Obsession with Rules and Regulation and the Aversion to being Ruled Regulated', in B Sageart, M Theebohm, C Timmerman \& B Vanreusel (eds), Sports Governance, Development and Corporate Responsibility, Routledge, Oxon, pp. 107-21.

Chang, Z 2018, 'Understanding the Corruption Networks Revealed in the Current Chinese Anti-corruption Campaign: A Social Network Approach', Journal of Contemporary China, vol. 27, no. 113, p. 735-47. doi:10.1080/10670564.2018.1458060

Chappelet, JL \& Mrkonjic, M 2013, Existing Governance Principles in Sport: A Review of Published Literature, ICSSPE, Berlin.

Di Francesco, M 2020, 'A Signal Failure: Sports Grants, Public Servants, and Traffic Lights', Australian Journal of Public Administration, vol. 79, no. 4, pp. 584-91. doi:10.1111/1467-8500.12434

DiMaggio, P \& Powell, W 1983, 'The Iron Cage Revisited: Institutional Isomorphism and Collective Rationality in Organisational Fields', American Sociological Review, vol. 48, no. 2, pp. 147-60.

Dorsey, JM 2015, 'How Qatar Is Its Own Worst Enemy', International Journal of the History of Sport, vol. 32, no. 3, pp. 422-39. doi:10.1080/09523367.2015.1008212 
Downing, M, Leopkey, B, \& Smith, L 2018, 'Governance in Sport: A Scoping Review', Journal of Sport Management, vol. 32, no 5, pp. 438-51. doi:10.1123/jsm.2018-0032

Eisenstadt,S(eds) 2017,MultipleModernities, Routledge,Oxon.doi:10.4324/9781315124872

Erturan-Ogut, EE \& Sahin, MY 2014, 'Political Clientelism in Turkish Sports Federations', European Sport Management Quarterly, vol. 14, no. 5, 556-66. doi:10.1080/16184742.2 014.950307

European Commission 2019, Sport: Good Governance, European Commission, Brussels.

European Parliament 2017, Briefing: Good Governance in Sport, European Parliament, Brussels.

Fan, Y 2002, 'Guanxi's Consequences: Personal Gains at Social Cost', Journal of Business Ethics, vol. 38, no. 4, pp. 371-80. doi:10.1023/A:1016021706308

Fourie, E 2012, 'A Future for the Theory of Multiple Modernities: Insights from the New Modernisation Theory', Social Science Information, vol. 51, no. 1, pp. 52-69. doi:10.1177/0539018411425850

Fukuyama, F 1993, The End of History?, Institute of Economic Affairs, London.

Geeraert A 2015, Sports Governance Observer 2015. The Legitimacy Crisis in International Sports Governance, Play the Game/Danish Institute for Sports Studies, Copenhagen.

Ghadami, M \& Henry, I 2015, 'Developing Culturally Specific Tools for the Evaluation of Good Governance in Diverse National Contexts: A Case Study of the National Olympic Committee of the Islamic Republic of Iran', The International Journal of the History of Sport, vol. 32, no. 8, pp. 986-1000. doi:10.1080/09523367.2015.1040223

Habermas, J 1984; 1987, Theory of Communicative Action, Vols. I and II, Beacon Press, Boston.

Habermas, J 1990, Moral Consciousness and Communicative Action, MIT Press, Cambridge, MA.

Habermas, J 1992, Justification and Application, Polity, Cambridge.

Habermas, J 1995, 'Reconciliation Through the Public Use of Reason: Remarks on John Rawls's Political Liberalism', Journal of Philosophy, vol. XCII, no. 3, pp. 117-18. doi: $10.2307 / 2940842$

Henry, I 2007, 'Bridging Research Traditions and World Views: Universalisation versus Generalisation in the Case for Gender Equity', in I Henry \& Institute of Sport and Leisure Policy (eds), Transnational and Comparative Research in Sport: Globalisation, Governance and Sport Policy, Routledge, Oxon.

Henry, I, Amara, M, Liang, J \& Uchiumi, K 2005, 'The Governance of Professional Soccer: Five Case Studies - Algeria, China, England, France and Japan', European Journal of Sport Science, vol. 5, no. 4, pp. 189-206. doi;10.1080/17461390500344503

Henry, I \& Lee, PC 2004, 'Governance and Ethics in Sport', in J Beech \& S Chadwick (eds), The Business of Sport Management, Pearson Education, London, pp. 25-41.

Henry, I \& Nassis, P 1999, 'Sport, Policy and Clientelism in Contemporary Greece', International Review for the Sociology of Sport, vol. 34, no. 1, pp. 43-58.

Hsu, CL 2005, 'Capitalism Without Contracts Versus Capitalists Without Capitalism: Comparing the Influence of Chinese Guanxi and Russian Blat on Marketisation', Communist and Post-Communist Studies, vol. 38, no. 3, pp. 309-27. doi:10.1016/j. postcomstud.2005.06.003

IOC 2008, Basic Universal Principles of Good Governance of the Olympic and Sports Movement, IOC, Lausanne.

Johnson, J 2001, 'Path Contingency in Postcommunist Transformations', Comparative Politics, vol. 33, no. 3, pp. 253-74. doi:10.2307/422403 
Kim, M \& Hodges, HJ 2005, 'On Huntington's Civilisational Paradigm: A Reappraisal', Issues $\mathcal{E}$ Studies, vol. 41, no. 2, pp. 217-48.

Li, L 2018, 'The Moral Economy of Guanxi and the Market of Corruption: Networks, Brokers and Corruption in China's Courts', International Political Science Review, vol. 39, no. 5, pp. 634-46. doi:10.1177/0192512118791585

McLaren, R 2016, 'Richard H. McLaren, O.C. Independent Person: Wada Investigation of Sochi Allegations', The Independent Person 2nd Report, December 9.

McLeod, J, Shilbury, D \& Zeimers, G 2020, 'An Institutional Framework for Governance Convergence in Sport: The Case of India', Journal of Sport Management, vol. 35, no. 2, pp. 144-57. doi:10.1123/jsm.2020-0035

Meisenbach, R 2006, 'Habermas's Discourse Ethics and Principle of Universalisation as a Moral Framework for Organisational Communication', Management Communication Quarterly, vol. 20, no. 1, pp. 39-62. doi:10.1177/0893318906288277

Milne, S 2012, The Revenge of History, Verso, London.

Morgan, L 2020, 'Two-week ban given to NFL player highlights anti-doping issues in US, WADA claim', Inside the Games, November 26.

Murphy, K 2020, 'Bridget McKenzie Resigns Following Sports Rorts Affair', Guardian, February 2.

Mussagulova, A 2020, 'Newly Independent, Path Dependent: The Impact of the Soviet Past on Innovation in Post-Soviet States', Asia Pacific Journal of Public Administration, pp. 1-19. doi:10.1080/23276665.2020.1805338

Nassis, P 1994, Analysis of Sports Policy in Greece, Through a Strategic Relations Perspective 1980-93, Dissertation, Loughborough University, Loughborough.

Onoshchenko, O \& Williams, CC 2014, 'Evaluating the Role of Blat in Finding Graduate Employment in Post-Soviet Ukraine The "Dark Side" of Job Recruitment?', Employee Relations, vol. 36, no. 3, 254-65. doi:10.1108/er-06-2013-0070

Osborne, D \& Gaebler, T 1992, Reinventing Government, Addison-Wesley, Reading, MA.

Reeves, A, Friedman, S, Rahal, C \& Flemmen, M 2017, 'The Decline and Persistence of the Old Boy: Private Schools and Elite Recruitment 1897 to 2016', American Sociological Review, vol. 82, no. 6, pp. 1139-66. doi:10.1177/0003122417735742

Saaty, T 1980, The Analytic Hierarchy Process, McGraw-Hill, New York. doi:10.21236/ ADA214804

Said, E 1991, Orientalism: Western Conceptions of the Orient, Penguin, London.

Sleightholm, M 2018, 'Middle East Ownership in European Football Sports Industry Series', Sport Industry Insider: Middle East Sport Business News, November 14.

Smith, R 1999, 'Visible and Invisible Cultures of Parliamentary Ethics: The 'sports Rorts' Affair Revisited', Australian Journal of Political Science, vol. 34, no. 1, pp. 47-62. doi: $10.1080 / 10361149950452$

Tibi, B 2001, Islam Between Culture and Politics, Palgrave, New York. doi:10.1057/ 9780230514140

Wang, P 2016, 'Military Corruption in China: The Role of Guanxi in the Buying and Selling of Military Positions', China Quarterly, vol. 228, pp. 970-91. doi:10.1017/ s0305741016001144

Williams, CC \& Yang, JH 2017, 'Evaluating the Use of Personal Networks to Circumvent Formal Processes: A Case Study of Vruzki in Bulgaria', South East European Journal of Economics and Business, vol. 12, no. 1, pp. 57-67. doi:10.1515/jeb-2017-0006

Winand, M \& Anagnostopoulos, C (eds) 2019, Research Handbook on Sport Governance, Edward Elgar Publishing, Cheltenham. doi:10.4337/9781786434821 
Wittgenstein, L (eds) 1972, Philosophical Investigations, Blackwell and Mott, Oxford.

Wittrock, B 2002, 'Modernity: One, None, or Many? European Origins and Modernity as a Global Condition', in S Eisenstadt (eds), Multiple Modernities, Transaction Publishers, London.

Wright, T 2020, 'Sports rorts is in order! The term was invented by the Speaker himself', Brisbane Times, January 27.

Zidan, K 2019, 'Sportswashing: How Saudi Arabia Lobbies the US's Largest Sports Bodies', The Guardian, September 2. 